\title{
Anmeldelser
}

idéhistorikere på den anden.

Man må håbe, at værket i sin helhed vil blive studeret ved Institut for Idéhistorie, hvor interessen for antikkens filosofiske tradition mig bekendt ikke har været overvældende, siden instituttets stifter Johannes Sløk forlod det.

Friis Johansens digre bind om antikkens filosofihistorie er særdeles nyttigt, men især er det filosofisk. Dæmper man for sit indre øre den patetiske kontekst: at falde ned i dette værk er som at falde ned i en meget dyb brønd, der jo som bekendt altid giver det klareste vand. Alvorligt talt.

Niels Grønkjær

\section{Hvor jødisk er den jødiske humor?}

Richard Raskin: Life is Like a Glass of Tea.

Studies of Classic Jewish Jokes, Aarhus

University Press, 1992, 264 sider, 178 kr.

Om denjødiske humor er der allerede skrevet digre værker og lærde afhandlinger, hvilket bogens fyldige bibliografi vidner om. Der findes tilmed en Encyclopedia of Jewish $\mathrm{Hu}$ mor, og der afholdes hvert år symposier om emnet. Richard Raskins bidrag adskiller sig imidlertid fra andre ved, at det er den første samlede undersøgelse af jødiske vittigheders betydning og udviklingshistorie.

Bogen indledes med et velvalgt citat, der virker mere besværgende end advarende. "Humor can be dissected as a frog can, but the thing dies in the process". En sympatisk påmindelse, når man har sat sig som mål at analysere seks klassiske jødiske vittigheder og følge deres udvikling op gennem tiderne for til sidst at give et bud på nogle specifikke træk, der skulle kendetegne en jødisk vittighed.

Efter en gennemgang af en mængde "jokes" og en fremdragelse af et sæt psykologiske forklaringer på den jodiske vittigheds selvfornedrende status - lige fra det masochistiske til det parodierende - som andre forskere er nået frem til, finder Raskin to egenskaber, der til gengæld skulle rumme essensen af en jødisk vittighed. Den første egenskab er, at pointen er åben for alternative valg af fortolkninger. Den anden er, at dette alternative valg kan anskues ud fra tre for- 


\section{Anmeldelser}

skellige grundlæggende perspektiver: ynkelig holdning, taktisk manøvre og eksemplarisk afvigelse.

Derudover bekræfter Raskin gennem sine analyser Christie Davies' bidrag til løsning af et helt andet problem, nemlig hvordan man bestemmer forskellen mellem en jødisk vittighed og en vittighed om jøder. Hvis man kan skifte jøden ud med f.eks. en skotte, er der ikke tale om en jødisk vittighed, men blot en vittighed omjøder.

Jeg ved ikke, om sagkyndige altid vil være enige med Raskin i alle hans synspunkter, eller hvorvidt han indfrier løftet om at afdække det autentiske jødiske islæt, der skulle kendetegne den klassiske jødiske vittighed. Det er i det hele taget et risikabelt foretagende, han har vovet sig ud i. Ved at følgeen vittigheds vandring og vækst og katalogisere de forskellige, ofte modstridende fortolkninger, er han endt med at skabe en fornyelse på dette felt ved at afsløre pointens iboendeåbenhed.

Når en klassisk jødisk vittighed er bedst, har dens pointe oven i købet en evne til at være reversibel. På samme måde som når man betragter Rubins tegning og skiftevis ser to forskellige figurer, således kan pointen også vakle mellem mindst to måder at blive anskuet på.

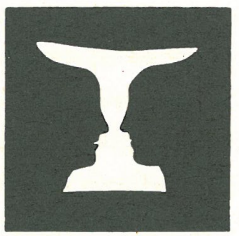

Den tilsvarende vittighed lyder: To jøder op- søger en rabbiner for at få afgjort en tvist. Som sædvanlig er rabbinerens kone til stede. Den første jøde fremlægger sit syn på sagen og forstår at belægge sine ord, hvorfor rabbineren til sidst vedgår: "Du har ret". Så henvender rabbineren sig til den anden jøde: "Og hvad har du så at sige til det?" Den anden jøde mener ikke, at han skylder nogen noget og forsvarer sig så dygtigt, at rabbineren ikke har noget at indvende. "Du har ret", siger han. Rabbinerens kone, der aldrig før har hørt noget lignende, vender sig mod sin mand: "Jamen, de kan da ikke have ret begge to, kan de?", "Det har du sandelig ret i".

Mærkelig nok spiller vittighedens oprindelse ikke nogen videre rolle for bestemmelsen af dens "jødiskhed". Den omtalte vittighed var oprindeligt etnisk neutral. Der var nemligtaleomendommeri stedet for en rabbiner, og en assessor i stedet for rabbinerens kone. Ikke desto mindre er vittigheden jødisk, ikke fordi den fik en ny rollebesætning, ej heller fordi den vandt udbredelse blandt joderne i USA, men snarere fordi den er åben for tre meget forskellige fortolkningsmuligheder: den ynkelige holdning, hvorpå rabbineren tackler situationen, den taktiske manøvre, han lægger for dagen og den eksemplariske afvigelse, han udviser inden for mulig menneskeligadfæerd.

Foruden pointens reversibilitet indeholder mange jødiske vittigheder en verbal pendant til en af disse umulige figurer som f.eks. Penroses trekant, Eschers billeder, eller den neden for viste tegning, der alle udfordrer deres egen logik i den grad, at man til sidst opgiver at finde ud af, hvordan de er "skruet sammen". 


\section{Anmeldelser}

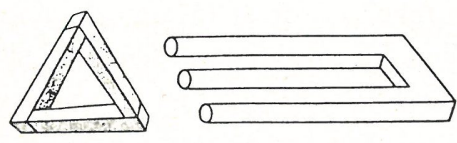

Vittigheden lyder: To jøder går en tur. Den ene har taget en paraply med. Pludselig begynder det at regne. "Skynd dig lidt, slå din paraply op", siger den ene. "Det nytter ikke", svarer den anden lakonisk. "Hvad skal det sige?", vedbliver manden uden paraply: "Ikke noget, paraplyen er gennemhullet som en si", "Hvorfor i himlens navn har du så taget den med?", "Arh.. Jeg vidste ikke det ville blive regnvejr".

En tredie karakteristik, man kan finde ved de bedste klassiske vittigheder, skulle anskueliggøre den ikke altid logiske menneskelige adfærd, der kan fremkalde den lige så usandsynlige humor. For eksempel den lethed, hvormed engelske piloter kunne ramme Shell-huset, Gestapos hovedkvarter i København, den eneste bygning der var camouflagemalet.

Et fjerde træk kan beskrives som en mistro over for ethvert ræsonnement, der forsøger at lokke forstanden i en fælde. Her kunne forfatteren været kommet en eventuel kritik i forkøbet ved at pege på mulige forskelle mellem dette træk og det tilsvarende, der minder om the impossible figure.

Skønt Raskin ikke udtømmer de fænomener, han taler om, er fremstillingen fuld af tankevækkende betragtninger og spækket med inciterende iagttagelser. Richard Raskin er lærd, men han bærer sin lærdom med den akademiske distance til stoffet, der gør læsningen behagelig.

Emile Danino

\section{Løgstrups historie}

Hans Hauge: K.E. Løgstrup. En moderne profet, Spektrum, 1992, 694 sider.

"'Jesu Liv var derfor uden den Fasthed, som Maalbevidsthed giver. Hans Liv var i absolut Forstand plan-løst. Derfor var han heller aldrig færdig, intet af det han gjorde var ham et Resultat, han havde Intet, han skulde have udrettet. Han talte og gjorde sine Gerninger dér, hvor han tilfældigvis gik og stod - for de Mennesker, han tilfældigvis mødte og kom i Forbindelse med.

Jesus forfulgte ikke sine Gerningers Virkninger. Han kom og gik. Han lod Mennesker komme - og han lod Mennesker gaa'.

Min påstand er i al korthed den, at det aktuelle og fascinerende ved en sådan skildring ikke består i, at den skulle ligge en værensfilosofisk eller religiøs tydning nær. Nærmere ligger skildringen på de muligheder, som moderniteten intonerer historisk men ikke selv realiserer."

Sådan kommenterede jeg Løgstrups Jesusskildring i hans disputats fra $1943 \mathrm{i}$ min artikel fra 1984 om Logstrups fire metafysikbind. Og den kommentar vil jeg stå ved også i dag. Selv om det er selvcentrerethed og måske såret forfængelighed at irriteres over, at Hans Hauge ikke så meget som nævner denne artikel i sin imponerende bog/disputats om "K.E. Løgstrup. En moderne profet", så skal jeg alligevel ikke undlade at vedstå denne irritation hér. Så meget mere som Hauges bog om Løgstrup faktisk er en bog om Logstrups 